\begin{tabular}{|} 
Ambiente \& Água - An Interdisciplinary Journal of Applied Science \\
ISSN 1980-993X - doi:10.4136/1980-993X \\
www.ambi-agua.net \\
E-mail: ambi.agua@gmail.com
\end{tabular}

\title{
Surveillance of public water supply fluoridation and municipal indicators: an analysis in the state of Espirito Santo, Brazil
}

\author{
ARTICLES doi:10.4136/ambi-agua.2693
}

Received: 11 Jan. 2021; Accepted: 03 May 2021

\author{
Ariane Mendonça ${ }^{1 *(D)}$; Katrini Guidolini Martinelli ${ }^{\circledR}$; \\ Carolina Dutra Degli Esposti2 ${ }^{-1}$; Lorrayne Belotti ${ }^{3}$; \\ Karina Tonini dos Santos Pacheco 4 (iD
}

\begin{abstract}
${ }^{1}$ Departamento de Medicina Social. Programa de Pós-Graduação em Clínica Odontológica. Universidade Federal do Espírito Santo (UFES), Avenida Marechal Campos, n¹468, CEP: 29047-105, Vitória, ES, Brazil.

${ }^{2}$ Departamento de Medicina Social. Programa de Pós-Graduação em Saúde Coletiva. Universidade Federal do Espírito Santo (UFES), Avenida Marechal Campos, n¹468, CEP: 29047-105, Vitória, ES, Brazil.

E-mail: katrigm@gmail.com, carolinaesposti@gmail.com

${ }^{3}$ Programa de Pós-Graduação em Saúde Pública. Faculdade de Saúde Pública. Universidade de São Paulo (USP), Avenida Doutor Arnaldo, n715, CEP: 01246-904, São Paulo, SP, Brazil. E-mail: lorraynebelotti@usp.br ${ }^{4}$ Programa de Pós- Graduação em Ciências Odontológicas. Universidade Federal do Espírito Santo (UFES), Avenida Marechal Campos, n¹468, CEP: 29047-105, Vitória, ES, Brazil. E-mail: kktonini@ yahoo.com.br

*Corresponding author. E-mail: arianemend@gmail.com
\end{abstract}

\begin{abstract}
This study investigated the demographic, socioeconomic, and municipal health indicators related to the quality of water fluoridation. An ecological study was carried out in Espirito Santo state (ES), based on data from the Drinking Water Quality Surveillance Information, from 2014 to 2017. The non-parametric Mann-Whitney and Spearman tests were applied to compare municipal indicators with the availability of information and the quality of fluoridation, respectively. Fluoridation quality was calculated to define the percentage of fluoride concentration values in each municipality within the range of the optimal level corresponding to the maximum benefit for preventing dental caries and minimum risk for the occurrence of dental fluorosis. The proportion of $80 \%$ or more samples were defined as a compliance criterion. In $2014,62.8 \%$ of the municipalities had information available, and $16.7 \%$ performed analyses of fluoride concentration. The percentage of available data increased about 30\%, in 2017, with $3.8 \%$ referring to fluoride. The quality of fluoridation remained high $(>80 \%)$ in ES in almost every year, except in 2014. The municipalities with the largest population, the highest GDP per capita, and the lowest coverage of the oral health team exhibited a greater availability of information about fluoride $(\mathrm{p}<0.05)$. The child mortality rate showed a strong negative correlation with the quality of fluoridation. The findings reinforce the importance of directing public policies that ensure the correct practices for monitoring and maintaining the quality of fluoridation.
\end{abstract}

Keywords: development indicators, environmental health surveillance, fluoridation.

This is an Open Access article distributed under the terms of the Creative Commons Attribution License, which permits unrestricted use, distribution, and reproduction in any medium, provided the original work is properly cited. 


\section{Vigilância da fluoretação da água de abastecimento público e indicadores municipais: uma análise no estado do Espírito Santo, Brasil}

\section{RESUMO}

O objetivo foi investigar os indicadores demográficos, socioeconômicos e de saúde municipais relacionados à qualidade da fluoretação da água. Estudo ecológico que abrangeu municípios do estado do Espirito Santo (ES), com base em dados Sistema de Informação de Vigilância da Qualidade da Água para Consumo Humano, no período de 2014 a 2017. Foram aplicados testes não paramétricos de Mann-Whitney e Spearman para comparar indicadores municipais com a disponibilidade de informação e a qualidade da fluoretação, respectivamente. A qualidade da fluoretação foi calculada para definir o percentual de valores de concentração de flúor dentro da faixa do nível ótimo correspondente ao máximo benefício e baixo risco para ocorrência de fluorose dentária. A proporção de $80 \%$ ou mais amostras foi definida como critério de conformidade. Em 2014, 62,8\% dos municípios possuíam informações disponíveis no sistema, e 16,7\% realizaram análises de concentração de flúor. O percentual de dados disponíveis aumentou cerca de $30 \%$, em 2017, sendo que 3,8\% foram referentes ao fluoreto. A qualidade da fluoretação manteve-se elevada ( $>80 \%$ ) no ES em quase todos os anos, exceto em 2014. Os municípios com maior população, maior PIB per capita e menor cobertura de equipe de saúde bucal apresentaram maior disponibilidade de informações sobre o fluoreto $(p<0,05)$. A taxa de mortalidade infantil apresentou forte correlação negativa com a qualidade da fluoretação. Os resultados encontrados reforçam a importância do direcionamento de políticas públicas que garantam a correta execução das atividades de monitoramento e manutenção da qualidade da fluoretação.

Palavras-chave: fluoretação da água, indicadores de desenvolvimento, vigilância sanitária ambiental.

\section{INTRODUCTION}

The fluoridation of public water supply is one of the most important measures of comprehensive coverage in public health, being recognized and recommended by the main World Health Organizations (Petersen, 2003). Since its implementation, surveys have shown that water fluoridation is effective at reducing the caries levels in both deciduous and permanent dentition in children (Iheozor-Ejiofor et al. 2015). Moreover, depending on the extent of the water supply system, it can reduce social inequality in access to fluoride and benefit the entire population, especially the most vulnerable (Slade et al., 2018; Spencer et al., 2018). Despite the control by the sanitation companies, some studies reinforce that the wide variation in fluoride levels in public water supply fluoridation, the relationship between inadequate levels and the interruption of the process and the rate of dental fluorosis, showing that it is necessary to implement surveillance systems by public institutions (Frazão et al., 2013; Scalize et al., 2018).

In Brazil, water quality control for human consumption was made a public responsibility action in 1977 by the passage of Federal Decree $n^{\circ} 79.367$, through Ordinance $n^{\circ} 56$ of the Ministry of Health. However, it was only at the end of the 1990s that the National Water Quality Surveillance Program for Human Consumption (Vigiagua) was created, which consists of the set of actions adopted to ensure the control and quality of the water consumed by the population. In order to assist in the management of information, the Drinking Water Quality Surveillance Information System (Sisagua) was developed, systematizing the data routinely generated by professionals in the health sector and those responsible for water supply services (Brasil, 2018). 
As a way to ensure the quality and effectiveness of water fluoridation, it is necessary not only to monitor the appropriate levels within the recommended range for each region, but to systematize this information in order to establish priorities, objectives and targets. In a study by Frazão et al. (2013), given the information registered in Sisagua, it was found that about half of the Brazilian municipalities (50.4\%) were not registered, and $12.3 \%$, although registered, did not feed the system at least four times a year. In the Southeast region, more than $50 \%$ of the municipalities in the state of Rio de Janeiro and São Paulo were not registered in Sisagua; however, in Espirito Santo (ES) the percentage was lower, around $26 \%$. In addition to the registration and feeding failures, studies indicate the large number of non-standard samples, the absence of collections, analysis and disclosure of fluoride levels, revealing a possible inadequacy in the fluoridation process and failure of the responsible surveillance (Venturini et al., 2016).

In order to improve the quality of available data and the development of surveillance actions on the fluoridation of public water supply in Brazil, the Vigifluor Project, developed through a partnership between the Collaborating Center of the Ministry of Health in Oral Health Surveillance (CECOL) and specialists in the areas of health surveillance, mapped the coverage of fluoridation of public water supply in municipalities with more than 50 thousand inhabitants and also identified the lack of information on the fluoridation of water supply (Frazão and Narvai, 2017a).

Some municipality-level characteristics, such as population size, per capita income, type of sanitation utility, water supply coverage, and human development index have been associated with both the quality of fluoridation and its process expansion and monitoring (Belotti et al. 2020; 2018; Frazão and Narvai, 2017b). Knowing that communities and countries with inadequate fluoridation processes have a higher risk of developing caries disease in their population, it is necessary to understand the relationship between municipal indicators and the fluoridation of public water supply as a way to validate the processes already implemented, identify possible problems and suggest changes aimed at water quality surveillance and, consequently, health promotion.

This study therefore investigated the demographic, socioeconomic, and municipal health indicators related to the quality of water fluoridation, which also includes the availability of information, in Espirito Santo state, Brazil.

\section{MATERIALS AND METHODS}

An ecological study was conducted based on the data regarding the fluoridation of public water supply and municipal demographic, socioeconomic and health indicators in the state of Espirito Santo (ES) from 2014 to 2017. The period was selected according to the availability of data and Version 4 of Sisagua. Located in the Southeast region of Brazil, the state is composed of 78 municipalities distributed among the health regions: Metropolitan; Central; North and South. The population is about 4,016,356. According to data from the National Survey of Basic Sanitation, all 78 municipalities in ES have piped and treated water (IBGE, 2017). Of the total population, 96.45\% live in households with running water (PNUD, 2010). According to data from the CECOL website, in 2016 100\% of the population of the capital Vitória had treated and fluoridated water.

Data related to external control of fluoridation were collected in the surveillance system (Sisagua) by an author. Considering the average maximum temperature in the state of ES, the criterion proposed by CECOL/USP (2011) was used to classify the fluoride concentration present in the samples according to the benefit in preventing caries and risk of dental fluorosis. This criterion is divided into six categories: insignificant benefit and risk $(0.00$ to $0.44 \mathrm{mg} \mathrm{F} / \mathrm{L})$; minimal benefit and low risk ( 0.45 to $0.54 \mathrm{mg} \mathrm{F} / \mathrm{L})$; maximum benefit and low risk $(0.55$ to $0.84 \mathrm{mg} \mathrm{F} / \mathrm{L}$ ); maximum benefit and moderate risk ( 0.85 to $1.14 \mathrm{mg} \mathrm{F} / \mathrm{L})$; questionable benefit 
and high risk (1.15 to $1.44 \mathrm{mg} \mathrm{F} / \mathrm{L}$ ); and harmfulness and very high risk (1.45 mg F/L or more).

The Fluoridation Quality Level (FQL) was calculated according to Belotti et al. (2018) Equation 1:

$$
F Q L=\frac{\text { No.of suitable samples }\left(0.55 \leq T_{\text {fluoride }} \leq 0.84\right)}{\text { Total number of samples }(n)} \times 100
$$

To estimate the quality of water fluoridation, the proportion of $80 \%$ or more samples was defined as a high level of quality (Pelletier, 2004). Considering that the control and quality of fluoridation can be assessed using some demographic, socioeconomic and municipal health indicators, the following indicators were selected from official sources and according to the years surveyed or the last census carried out:

- Total population: the availability of treated and fluoridated water tends to be higher in municipalities with a larger population size (Roncalli et al., 2019; Belotti et al., 2020).

- Gross Domestic Product (GDP) per capita: municipalities with better economic indicators can be associated with a better quality of fluoridation (Belotti et al., 2020).

- Gini Index (0 to 1): the lack of registration and food in the Sisagua system has been associated with municipalities with the worst social and economic indicators (Frazão et al., 2013)

- Municipal Human Development Index (MHDI): an index that assesses the quality of life and economic development of a population (UNDP, 2010), being able to detect the risk of mortality, the quality of the water offered and, consequently, life expectancy, through basic sanitation and economy (Frazão and Narvai, 2017b).

- Percentage of the population in households with running water: this indicator directly influences access to fluoridated water, limiting this portion of the population to enjoy the benefits of fluoridation.

- Child mortality rate: it is considered a universal indicator in studies that analyze issues that affect the basic sanitation of the population, mainly in children up to 1 year old, as they are more sensitive to several pathologies (Carvalho et al., 2015)

- Hospitalization rates due to diarrhea: the occurrence of diarrhea is linked to access to treated water and environmental sanitation (WHO, 2009). The contamination of the water supplied by the public supply network reveals a flaw in its external control, reflecting the presence of possible irregularities in the control of the fluoride parameter.

- Coverage by oral health teams (COHT): indicator established based on the organization and structuring of the health system (Fernandes and Peres, 2005), attributing a possible correlation between the municipalities with better coverage and the quality of water fluoridation.

- Percentage of extractions in relation to the total of dental procedures: the increase in the number of mutilating procedures may serve as a warning for the presence of possible flaws in the external control of water fluoridation, considering that the decline in the values of the DMFT index (index of decayed, missing and filled teeth) is related to cities that have fluoridated water (Belotti et al., 2018).

- Average of supervised tooth brushing: it is considered one of the priorities of the National Oral Health Policy, aiming at the prevention of oral diseases, mainly dental caries (Brasil, 2004), thus being an indicator of the effectiveness in the offer of public policies aimed at oral health.

Descriptive analyses were performed by calculating absolute and relative frequencies for qualitative variables, and median and interquartile distance for quantitative variables. To analyze the association between municipal indicators and the control of available data regarding fluoridation (municipalities with and without recorded data, at least one month of the year), the Mann-Whitney nonparametric test was performed (comparison of medians), with p-value $\leq$ 
0.05 and $95 \%$ confidence interval, as the data did not present a normal distribution. Considering only the municipalities that fed the system with fluoridation data in some of the years studied, the nonparametric Spearman test was performed to analyze the correlation between municipal indicators and the quality of fluoridation (FQL). P-value $\leq 0.05$ and $95 \%$ confidence interval were also used. The data were stored in the program Statistical Package for the Social Sciences (SPSS), Version 20.0.

\section{RESULTS AND DISCUSSION}

Analyzing the availability of information regarding the external control of public water supply in 2014, of the 78 municipalities that make up the state of ES, only $49(62.8 \%)$ recorded data related to the analysis of public water supply in the Sisagua, of which only $13(16.7 \%)$ had data on the fluoride parameter. In 2017, the number of municipalities with available data increased to $72(92.3 \%)$; however, only $16(20.5 \%)$ analyzed fluoride concentration. The Metropolitan region had the highest number of municipalities with data records between the years $2014(60.0 \%)$ and 2017 (80\%). On the other hand, the Central, North and South regions did not provide data on fluoridation control for most of the period analyzed. Among the samples with analysis of the fluoride concentration, in all the state, the percentage of the samples with content considered: (a) "adequate" - ranged from 70.7\% to $87.6 \%$; (b) "inadequate" - below ranged from $5.1 \%$ to $23.6 \%$; and (c) "inadequate" - above ranged from $1.0 \%$ to $7.3 \%$ (Table 1 ).

Table 1. Distribution of available data on the external control and of the quality of fluoridation in the municipalities of Espirito Santo in the period from 2014 to 2017.

\begin{tabular}{lcccc}
\hline & $\begin{array}{c}2014 \\
\mathrm{n}(\%)\end{array}$ & $\begin{array}{c}2015 \\
\mathrm{n}(\%)\end{array}$ & $\begin{array}{c}2016 \\
\mathrm{n}(\%)\end{array}$ & $\begin{array}{c}2017 \\
\mathrm{n}(\%)\end{array}$ \\
\hline Available data (n=78) & & & & \\
\hline Control of public water supply & $49(62.8)$ & $73(93.6)$ & $68(87.2)$ & $72(92.3)$ \\
Control of fluoride parameter & $13(16.7)$ & $16(20.5)$ & $15(19.2)$ & $16(20.5)$ \\
\hline Fluoridation data by health region (n) & & & \\
\hline Metropolitan (20) & $12(60.0)$ & $16(80.0)$ & $15(75.0)$ & $16(80.0)$ \\
Central (18) & $0(0.0)$ & $0(0.0)$ & $0(0.0)$ & $0(0.0)$ \\
North (14) & $01(7.1)$ & $0(0.0)$ & $0(0.0)$ & $0(0.0)$ \\
South (26) & $0(0.0)$ & $0(0.0)$ & $0(0.0)$ & $0(0.0)$ \\
\hline Quality of fluoridation & \multicolumn{5}{|c}{} \\
\hline Total samples with [ ] of fluoride & 692 & 1.177 & 1.308 & 713 \\
[ ] Inadequate Below & $163(23.6)$ & $60(5.1)$ & $105(8.0)$ & $93(13.0)$ \\
[ ] Adequate & $489(70.7)$ & $1.031(87.6)$ & $1.155(88.3)$ & $613(86.0)$ \\
[ ] Inadequate Above & $40(5.8)$ & $86(7.3)$ & $48(3.7)$ & $07(1.0)$ \\
\hline
\end{tabular}

Note: [ ] concentration; [ ] inadequate below: 0 to $0.54 \mathrm{mg}$ F/L; [ ] adequate: 0.55 to 0.84 $\mathrm{mg} \mathrm{F} / \mathrm{L}$; [ ] inadequate above: equal to or greater than $0.85 \mathrm{mg} \mathrm{F} / \mathrm{L}$.

Considering only the municipalities that performed the analysis of the fluoride concentration in any year surveyed, the sampling plan (minimum recommended number of samples to be analyzed in the fluoride parameter) was compared with the number of samples in which included an analysis of fluoride concentration. None of these municipalities analyzed the minimum number of samples in all consecutive years. More than half of the municipalities that performed an analysis of the fluoride concentration had the quality level of fluoridation equal 
to or above $80 \%$, indicating a high level of quality, except in 2014 (Table 2).

In this study, there was a significant increase (almost 30\%) in the registration of data in Sisagua regarding the water supply surveillance between 2014 and 2017. Even so, the analysis of the fluoride parameter was reduced, presenting an increase of only $3.8 \%$ in the years surveyed. The lack of analysis of the fluoride parameter in a municipality in the state of ES was also reported by Belotti et al. (2019) through an interview with water surveillance system workers. Roncalli et al. (2019), assessing municipalities with more than 50 thousand inhabitants in Brazil, observed a significant improvement in the registration of data on external control of water in the surveillance information system; however, the percentage of data referring to the analysis of the fluoride parameter was still deficient.

Table 2. Numerical and percentage distribution of the annual sampling plan, the number of samples with analysis of fluoride concentration and the number of samples considered adequate (according to classification criteria CECOL/USP) by municipality in the state of ES, in the period from 2014 to 2017.

\begin{tabular}{|c|c|c|c|c|c|c|c|c|c|}
\hline \multirow[b]{2}{*}{ Municipalities } & \multirow[b]{2}{*}{$\begin{array}{l}\text { S.P } \\
(n)\end{array}$} & \multicolumn{2}{|c|}{2014} & \multicolumn{2}{|c|}{2015} & \multicolumn{2}{|c|}{2016} & \multicolumn{2}{|c|}{2017} \\
\hline & & $\begin{array}{c}\text { S.A } \\
\text { (n) }\end{array}$ & $\begin{array}{c}\text { FQL } \\
(\%)\end{array}$ & $\begin{array}{l}\text { S.A } \\
\text { (n) }\end{array}$ & $\begin{array}{c}\text { FQL } \\
(\%)\end{array}$ & $\begin{array}{c}\text { S.A } \\
\text { (n) }\end{array}$ & $\begin{array}{c}\text { FQL } \\
(\%)\end{array}$ & $\begin{array}{l}\text { S.A } \\
\text { (n) }\end{array}$ & $\begin{array}{c}\text { FQL } \\
(\%)\end{array}$ \\
\hline Afonso Claudio & 60 & $*$ & $*$ & $*$ & $*$ & 4 & 100 & 18 & 22.2 \\
\hline Brejetuba & 60 & 8 & 100 & 8 & 100 & 12 & 100 & 2 & 100 \\
\hline Cariacica & 156 & $*$ & $*$ & 1 & 100 & 86 & 80.2 & 54 & 85.2 \\
\hline Conceição do Castelo & 60 & 16 & 75.0 & 37 & 91.9 & 40 & 95.0 & 15 & 93.3 \\
\hline Domingos Martins & 60 & 16 & 37.5 & 54 & 70.4 & 9 & 66.7 & 6 & 33.3 \\
\hline Fundão & 60 & $*$ & $*$ & $*$ & $*$ & 30 & 93.3 & 30 & 90.0 \\
\hline Guarapari & 108 & 81 & 90.1 & 204 & 90.2 & 207 & 89.9 & 107 & 93.5 \\
\hline Ibatiba & 60 & 20 & 75.0 & 54 & 88.9 & 35 & 94.3 & 22 & 81.8 \\
\hline Itaguaçu & 60 & $*$ & $*$ & 31 & 54.8 & $*$ & $*$ & 5 & 100 \\
\hline Itarana & 60 & 23 & 73.9 & 56 & 73.2 & 51 & 66.7 & 25 & 52.0 \\
\hline Laranja da Terra & 60 & 11 & 100 & 3 & 66.7 & $*$ & $*$ & $*$ & $*$ \\
\hline Santa Maria de Jetibá & 60 & 2 & 100 & 9 & 100 & 71 & 91.5 & 30 & 90.0 \\
\hline Santa Teresa & 60 & $*$ & $*$ & 8 & 100 & $*$ & $*$ & $*$ & $*$ \\
\hline São Mateus & 108 & 132 & 11.4 & $*$ & $*$ & $*$ & $*$ & $*$ & $*$ \\
\hline Serra & 156 & 134 & 89.6 & 214 & 88.8 & 208 & 92.8 & 105 & 82.9 \\
\hline $\begin{array}{l}\text { Venda Nova do } \\
\text { Imigrante }\end{array}$ & 60 & 20 & 100 & 37 & 100 & 20 & 90.0 & 23 & 95.7 \\
\hline Viana & 84 & $*$ & $*$ & 2 & 100 & 35 & 80.0 & 15 & 73.3 \\
\hline Vila Velha & 156 & 85 & 71.8 & 208 & 90.9 & 227 & 85.0 & 83 & 84.5 \\
\hline Vitória & 156 & 144 & 89.6 & 251 & 88.8 & 273 & 90.8 & 173 & 94.8 \\
\hline
\end{tabular}

Note: S.P: Sampling Plan according to Brasil (2014); S.A: Samples Analyzed; FQL: Fluoridation Quality Level *No information available.

Considering the availability of data by health region, only the municipalities in the Metropolitan health region maintained greater regularity in recording external control of fluoridation in Sisagua. The result can be justified by the high number of smaller municipalities in the other health regions of ES, revealing the influence of demographic, socioeconomic and health inequality in different regions in the same state and the success of the activities developed by the surveillance sector, in which less-developed regions face greater difficulties in carrying out all actions relevant to the water quality and control program. When investigating the 
perception of professionals in the sector responsible for the Vigiagua program in a small municipality, Queiroz et al. (2012) identified that, although there was a record of the data, no analysis or planning of this information was carried out, which demonstrates the difficulty of political organization in these regions.

Even with the better control of information in Sisagua found in this research, workers responsible for the Vigiagua Program in some municipalities that make up the Metropolitan health region also reported difficulties faced in the daily life of the sector, such as work overload, lack of initial training related to the activities of the water surveillance program, deficiency and structural limitation of the sector itself, lack of inputs in the laboratory responsible for the analyses and delay in the reports. The lack of disclosure of the results obtained through the external control process was also pointed out, showing an important noncompliance with the legislation (Belotti et al., 2019).

The quality level of fluoridation in the state of ES was considered high in almost all the years surveyed. Belotti et al. (2018) reported optimal fluoride levels in the metropolitan region of Great Vitória, where, despite some irregularities, the quality standard remained high. Other studies that analyzed the quality of fluoridation using the classification criteria for maximum benefit and low risk found results similar to those of this research, considering the same concentration range as appropriate (Buzalaf et al., 2013; Bergamo et al., 2015).

Among the samples in noncompliance with the ideal standard, most of them were below the fluoride dosage suitable for the state of ES. The prevalence of samples with concentrations below those recommended by the current legislation and by CECOL was also identified in other studies (Brito et al., 2016; Scalize et al. 2018). In view of the precarious access of a large part of the population to other preventive methods and dental treatment, which is still present today, the absence or insufficient levels of fluoride in public water supply directly affect low-income populations (Alves et al., 2012).

Although the information was recorded in the system, the results found in this research may not reflect the quality of fluoridation offered to the population of ES, given the reduced number of samples with analysis of fluoride concentration. Among the municipalities with data on fluoridation, less than half analyzed the minimum number of samples established annually, indicating noncompliance with the legislation. It is worth mentioning that the sampling plan is defined by the municipalities in accordance with the National Guidelines for the Vigiagua Sampling Plan. This analysis is done on a preventive basis in order to maintain quality and avoid the inherent risks of fluoridation (Brasil, 2018).

In a report released by the Ministry of Health based on data recorded in Sisagua, amounts of samples analyzed by surveillance in the state of ES in 2018 were also found, below the number recommended by the National Directive for the residual parameters of the infectious agent, turbidity and fecal coliforms, in which 53\%,68.1\% and $96.6 \%$, respectively, of the total mandatory samples were analyzed (Brasil, 2018). Oliveira Junior et al. (2019), exploiting the surveillance system, also identified the quantity of water monitoring data for human consumption lower than that established by the sampling plan of Vigiagua, both in the information relevant to the sanitation company (control) and the surveillance (external control).

The complexity of the water distribution network, the difficulties in transporting the collected samples, the insufficient capacity and the deficiency in the structure of the analysis laboratories are some factors that can contribute to the inadequacy of the operationalization of the method and, consequently, to the achievement of the sampling plan. Other factors related to the unavailability of financial resources, difficulty in maintaining adequate fluoride content due to the small range of recommendation and deficiency in the training of sanitation professionals responsible for fluoridation are also pointed out as difficulties that directly impact control and maintenance of adequate fluorine content and even the systematization of data generated by surveillance (Cesa et al., 2011; Moimaz et al., 2015). However, in order to 
guarantee the effectiveness (protection against dental caries) and safety (avoidance of risk of dental fluorosis) of fluoridation, it is necessary that the responsible public authority ensures not only the addition of fluoride but the adequacy of the added concentration levels (Piorunneck $e t$ al., 2017).

The availability, access and use of data produced by the surveillance in addition to sharing this data with the public water supply companies responsible for the distribution of water are of extreme importance for decision making in the health sector in structuring and expansion, not only of fluoridation, but of all aspects related to water quality throughout the country. Furthermore, since these data are available, it contributes to the evaluation of the performance of the actions developed by the surveillance and sanitation companies in the possible challenges faced by the sector and in the development of new activities, aiming to guarantee the maintenance of the positive effects of fluoridation.

The association between the availability of data and the municipal indicators revealed that the coverage of the oral health team showed a statistically significant result $(p \leq 0.05)$ in all years of the research, indicating that the municipalities with unavailability fluoridation data had a higher median ESB coverage. In 2016, the Gross Domestic Product showed a statistically significant result $(\mathrm{p} \leq 0.05)$, which reveals that the municipalities with available data on fluoridation had a higher GDP. The total population indicator also showed a statistically significant result $(\mathrm{p} \leq 0.05)$ for the years 2016 and 2017, indicating that the municipalities with available data on fluoridation had larger populations (Table 3).

The association between greater coverage of the oral health team and the absence of recorded fluoridation data could be explained because, in this study only the metropolitan health region, which comprises a large part of the municipalities with the largest total population, showed these data. In general, large municipalities tend to have less coverage of oral health teams than those with smaller populations (Fischer et al., 2010). It is recognized that the benefits derived from better management of water resources occur much more quickly in large urban centers and metropolitan regions, where the highest levels of income and the greatest technical and business training are concentrated (Tucci et al., 2000).

These statements were reinforced, since the availability of data on fluoridation was associated with more populous and higher GDP municipalities in the state of ES. This finding highlights that the effectiveness of the surveillance information system in the fluoride parameter is unequal and could be related to the better municipal conditions of the structure, organization, and human resources in the water quality control program. Frazão et al. (2013) identified the association between underfeeding and lack of registration in Sisagua with smaller municipalities and with worse economic, health and human development indicators nationwide.

According to the Inventory of the National Water Quality Surveillance Program for Human Consumption, some municipalities in the state of Acre, without data recorded in the surveillance system, reported the following difficulties: not having health surveillance actions, unavailability of internet and computers for registration of data generated by Vigiagua and lack of knowledge of the water surveillance program (Brasil, 2018). The reduced number of collaborators in the health surveillance team can interfere in the accomplishment of the activities of collecting and feeding the database, given the possible overload of functions that apply in carrying out all the actions inherent to the responsible sector, the low valuation of the professional and high turnover in teams, contributing to possible failures during the planning and analysis processes of the information generated (Campos et al., 2015; Belotti et al. 2019).

When correlating the quality of fluoridation with municipal indicators, only the child mortality rate in 2014 showed a statistically significant result $(\mathrm{p}<0.001)$, revealing a strong negative correlation, that is, the lower the percentage of suitable samples, the higher the child mortality rate (Table 4). 
Table 3. Association between municipal indicators and the availability of data on the external control of fluoridation of public water supply in the state of ES, from 2014 to 2017.

\begin{tabular}{|c|c|c|c|}
\hline Municipal Indicators & Available Median (P25-P75) & Unavailable Median (P25-P75) & P-value* \\
\hline & \multicolumn{3}{|c|}{2014} \\
\hline Tatol Donulation (2014) & 34,239 & 16,946 & 0224 \\
\hline rotal Population (2014) & $(12,692.5-237,386)$ & $(12,057-29,920)$ & 0.224 \\
\hline GDP (2014) & $\begin{array}{c}16,290.06 \\
(14,674.9-25,152.0)\end{array}$ & $\begin{array}{c}15,306.40 \\
(11,449.2-20,305.6)\end{array}$ & 0.252 \\
\hline Gini Index (2010) & $0.50(0.48-0.57)$ & $0.50(0.49-0.53)$ & 0.421 \\
\hline MHDI (2010) & $0.68(0.66-0.73)$ & $0.68(0.67-0.71)$ & 0.365 \\
\hline \% Piped Water (2010) & $91.28(87.42-98.18)$ & $94.81(90.93-96.95)$ & 0.722 \\
\hline Child Mortality Rate (2014) & $10.47(7.73-12.64)$ & $11.04(7.87-18.65)$ & 0.446 \\
\hline Hospitalization rates due to diarrhea (2014) & $4.39(0.90-13.94)$ & $6.90(0.20-24.13)$ & 0.920 \\
\hline COHT (2014) & $48.19(20.15-65.14)$ & $76.20(51.23-99.59)$ & 0.018 \\
\hline \% of Tooth Extractions in relation to Dental Procedures (2014) & $2.89(1.96-5.14)$ & $3.80(2.85-6.14)$ & 0.116 \\
\hline \multirow[t]{2}{*}{ Average of Supervised Tooth Brushing (2014) } & $1.65(1.00-8.27)$ & $1.36(0.38-4.05)$ & 0.202 \\
\hline & \multicolumn{3}{|c|}{2015} \\
\hline Total Ponulation (2015) & 29,830 & $17,965.5$ & 0161 \\
\hline fotal I Opulation (2010) & $(13,281.75-296,856.75)$ & $(11,987.75-30,795.50)$ & 0.101 \\
\hline GDP (2015) & $\begin{array}{c}17,628.25 \\
(14,920.2-24,076.6)\end{array}$ & $\begin{array}{c}16,481.13 \\
(12,566.7-20,112.9)\end{array}$ & 0.190 \\
\hline Gini Index (2010) & $0.49(0.47-0.53)$ & $0.51(0.49-0.53)$ & 0.331 \\
\hline MHDI (2010) & $0.69(0.67-0.73)$ & $0.68(0.66-0.71)$ & 0.287 \\
\hline \% Piped Water (2010) & $91.65(88.29-98.63)$ & $94.82(90.80-96.93)$ & 0.805 \\
\hline Child Mortality Rate (2015) & $10.41(9.04-15.56)$ & $12.19(7.87-16.43)$ & 0.904 \\
\hline Hospitalization rates due to diarrhea (2015) & $3.66(1.17-10.74)$ & $7.43(0.23-24.25)$ & 0.675 \\
\hline COHT (2015) & $53.30(17.41-82.94)$ & $77.87(55.19-97.57)$ & 0.050 \\
\hline \% of Tooth Extractions in relation to Dental Procedures (2015) & $3.60(2.37-5.86)$ & $4.37(3.06-5.98)$ & 0.366 \\
\hline Average of Supervised Tooth Brushing (2015) & $1.60(0.48-2.51)$ & $1.54(0.27-3.97)$ & 0.963 \\
\hline
\end{tabular}




\begin{tabular}{|c|c|c|c|}
\hline \multicolumn{4}{|l|}{ Continued... } \\
\hline & \multicolumn{3}{|c|}{2016} \\
\hline Total Population (2016) & $\begin{array}{c}34,589 \\
(20,376-359,555)\end{array}$ & $\begin{array}{c}16,339 \\
(11,957-29,743)\end{array}$ & $\mathbf{0 . 0 0 3}$ \\
\hline GDP (2016) & $\begin{array}{c}19,826.5 \\
(17,124.8-26,483.8)\end{array}$ & $\begin{array}{c}16,574.3 \\
(14,302.8-20,763.8)\end{array}$ & 0.026 \\
\hline Gini Index (2010) & $0.50(0.47-0.53)$ & $0.50(0.49-0.53)$ & 0.909 \\
\hline MHDI (2010) & $0.69(0.67-0.73)$ & $0.68(0.66-0.71)$ & 0.264 \\
\hline \% Piped Water (2010) & $92.73(87.72-99.07)$ & $94.18(90.84-96.91)$ & 0.884 \\
\hline Child Mortality Rate (2016) & $10.25(8.98-14.70)$ & $12.52(9.85-16.00)$ & 0.262 \\
\hline Hospitalization rates due to diarrhea (2016) & $5.97(0.93-12.70)$ & $4.49(0.29-18.11)$ & 0.960 \\
\hline COHT (2016) & $46.88(20.16-52.76)$ & $77.97(55.83-96.43)$ & 0.001 \\
\hline \% of Tooth Extractions in relation to Dental Procedures (2016) & $3.87(2.85-6.15)$ & $4.84(2.93-7.19)$ & 0.385 \\
\hline \multirow[t]{2}{*}{ Average of Supervised Tooth Brushing (2016) } & $1.65(0.27-2.73)$ & $0.49(0.02-2.13)$ & 0.149 \\
\hline & \multicolumn{3}{|c|}{2017} \\
\hline Total Population (2017) & $\begin{array}{c}33,559 \\
(16,300.5-303,146.5)\end{array}$ & $\begin{array}{c}16,856.5 \\
(11,870.75-30,222.25)\end{array}$ & 0.006 \\
\hline GDP (2017) & $\begin{array}{c}20,322.5 \\
(16,487.8-26,809.5)\end{array}$ & $\begin{array}{c}17,023.5 \\
(14,144.8-20,923.9)\end{array}$ & 0.054 \\
\hline Gini Index (2010) & $0.49(0.47-0.53)$ & $0.50(0.49-0.53)$ & 0.573 \\
\hline MHDI (2010) & $0.69(0.67-0.73)$ & $0.68(0.66-0.71)$ & 0.225 \\
\hline \% Piped Water (2010) & $92.38(88.00-98.63)$ & $94.49(90.80-96.93)$ & 1.000 \\
\hline Child Mortality Rate (2017) & $8.93(5.93-10.81)$ & $10.60(5.10-15.69)$ & 0.400 \\
\hline Hospitalization rates due to diarrhea (2017) & $3.63(0.63-10.55)$ & $3.39(0.00-17.80)$ & 0.951 \\
\hline COHT (2017) & $39.78(19.79-59.86)$ & $76.28(51.86-95.33)$ & 0.002 \\
\hline \% of Tooth Extractions in relation to Dental Procedures (2017) & $4.19(2.57-6.39)$ & $4.06(2.67-6.31)$ & 0.975 \\
\hline Average of Supervised Tooth Brushing (2017) & $0.46(0.02-1.64)$ & $0.16(0.00-1.21)$ & 0.500 \\
\hline
\end{tabular}

*Mann-Whitney Test: Bold indicates significance on the $95 \%$ confidence limit.

a- 2014: available (13), unavailable (65); b- 2015 and 2017: available (16), unavailable (62); c- 2016: available (15), Unavailable (63) 
Table 4. Correlation between municipal indicators and the percentage of samples suitable for fluoride concentration (according to CECOL/USP classification criteria) in the state of ES, in the period from 2014 to 2017.

\begin{tabular}{lcccc}
\hline Municipal Indicators & $\mathbf{2 0 1 4}$ & $\mathbf{2 0 1 5}$ & $\mathbf{2 0 1 6}$ & $\mathbf{2 0 1 7}$ \\
& $\mathbf{r}$ (p-valor) & $\mathbf{r}$ (p-valor) & $\mathbf{r}$ (p-valor) & r (p-valor) \\
\hline Total Population & -.251 & .213 & -.302 & -.252 \\
GDP & $(0.408)$ & $(0.429)$ & $(0.274)$ & $(0.347)$ \\
Gini Index & -.017 & .337 & -.324 & -.018 \\
& $(0.957)$ & $(0.202)$ & $(0.240)$ & $(0.948)$ \\
MHDI & -.003 & .310 & .218 & .231 \\
& $(0.993)$ & $(0.243)$ & $(0.435)$ & $(0.389)$ \\
\% Piped Water & -.232 & .170 & -.369 & .179 \\
& $(0.446)$ & $(0.529)$ & $(0.177)$ & $(0.507)$ \\
Child Mortality Rate & -.344 & .026 & -.461 & -.008 \\
& $(0.250)$ & $(0.923)$ & $(0.084)$ & $(0.976)$ \\
Hospitalization rates due to diarrhea & -.900 & .072 & .026 & 0.339 \\
& $(<\mathbf{0 . 0 0 1})$ & $(0.799)$ & $(0.929)$ & $(0.199)$ \\
COHT & .215 & .024 & .203 & -.190 \\
Percentage of Tooth Extractions in relation & $(0.502)$ & $(0.934)$ & $(0.527)$ & $(0.535)$ \\
to Dental Procedures & .493 & -.133 & .071 & -.021 \\
Average of supervised tooth brushing & $(0.087)$ & $(0.623)$ & $(0.800)$ & $(0.940)$ \\
& -.218 & -.379 & -.057 & -.208 \\
& $(0.475)$ & $(0.148)$ & $(0.839)$ & $(0.440)$ \\
& .276 & .085 & -.239 & -.246 \\
& $(0.361)$ & $(0.756)$ & $(0.390)$ & $(0.357)$ \\
\hline
\end{tabular}

The child mortality rate is considered an important indicator in public health, being widely used to analyze the level of health and quality of life in different regions, due to the sensitivity of the child population to different pathologies and environmental factors. This rate could reflect the quality of water supply and sewage in health (Carvalho et al., 2015). In this study, the correlation found between the child mortality rate and the quality of fluoridation, only in the year 2014, can be justified by the greater number of samples considered inadequate in the same year, when compared to the following years surveyed. It suggests that regions with higher values of this index have possible irregularities in the quality of public water supply. The relationship between the quality of fluoridation and the child mortality rate was also found in the study by Belotti et al. (2018), undertaken in the Grande Vitória Metropolitan Region.

The limitations relevant to this study correspond to the lack of data available by most municipalities in the surveillance system. During the bibliographic survey process, a small number of studies were identified with analysis of data generated specifically by Sisagua, not only in the state of Espirito Santo, but also in Brazil, revealing an important research gap regarding the analysis of the surveillance organization due to the external control of fluoridation of public water supply.

The absence of data regarding external control of water points to a major failure in the surveillance of some municipalities and the need for improvements in the water quality and control program, as a way to assist in the correct interpretation of the data generated and in the prioritization of strategies aimed at the surveillance of water, thus ensuring the achievement of the purpose for which Sisagua sets out. It should be noted that the methodology used in this research can be reproduced in all regions of the country and even in other countries, analyzing not only the fluoride parameter, but also taking into account other parameters recommended by sanitation programs around the world.

For fluoridation to be able to actually exercise its role as a social measure, greater investments are needed in technical, human and financial resources in the sector responsible for monitoring water for human consumption. However, for this to happen, the interest not only of 
political representatives, public servants and managers of water supply companies, but also of the community itself is extremely important, guaranteeing better quality of life.

\section{CONCLUSION}

The state of Espirito Santo showed a significant improvement with regard to the registration of data generated by surveillance due to the monitoring of public water supply. However, the number of municipalities that performed analysis of the fluoride concentration is still small and is concentrated almost entirely in the metropolitan region of health. Considering the quality of fluoridation, the level remained high; however, no municipality complied with the sampling plan in all years. The results exhibited that the larger the total population and the coverage of the oral health team, the higher the record of the system data. On the other hand, regarding the quality of fluoridation, the municipalities with the higher infant mortality rate showed lowest quality. This reinforces the importance of directing public policies that ensure the correct execution of activities aimed at monitoring fluoridation, in addition to encouraging research that analyzes not only the implementation but the maintenance of the quality of the fluoride parameter through social determinants as a way to reduce inequalities and guarantee access and use of services in an egalitarian way.

\section{ACKNOWLEDGMENTS}

To the State for Health's Secretary of the state of Espírito Santo, for allowing access to information on heterocontrol of public water available in Sisagua. And to the Environmental Surveillance team of the state, for their collaboration with the research.

\section{REFERENCES}

ALVES, R. X. et al. Evolução do acesso à água fluoretada no Estado de São Paulo, Brasil: dos anos 1950 à primeira década do século XXI. Cadernos de Saúde Pública, v. 28, p. s69s80, 2012. http://dx.doi.org/10.1590/S0102-311X2012001300008

BELOTTI, L. et al. Quality of the water fluoridation and municipal-level indicators in a Brazilian metropolitan region. Revista Ambiente \& Água, v. 13, n. 6, p. 1-15, 2018. http://dx.doi.org/10.4136/ambi-agua.2270

BELOTTI, L. et al. Vigilância da qualidade da água para consumo humano: potencialidades e limitações com relação à fluoretação segundo os trabalhadores. Saúde Debate, v. 43, n. especial 3, p. 51-62, 2019. http://dx.doi.org/10.1590/0103-11042019s304

BELOTTI, L. et al. Municipality-Level Characteristics Associated with Very Low to Good Quality of Water Fluoridation in São Paulo State, Brazil, in 2015. JDR Clinical \& $\begin{array}{llllllll}\text { Translational Research, } & \text { v. } 20, \quad \text { n. } 10, & \text { p. } & 1-11, & \end{array}$ https://doi.org/10.1177/2380084420970867

BERGAMO, E. T. P.; BARBANA, M.; TERADA, R. S. S.; CURY, J. A.; FUJIMAKI, M. Fluoride concentrations in the water of Maringá, Brazil, considering the benefit/risk balance of caries and fluorosis. Brazilian Oral Research, v. 29, n. 1, p. 1-6, 2015. http://dx.doi.org/10.1590/1807-3107BOR-2015.vol29.0047

BRASIL. Ministério da Saúde. Diretrizes da política nacional de saúde bucal. Brasília, DF, 2004. 
BRASIL. Ministério da Saúde. Diretriz nacional do plano de amostragem da vigilância em saúde ambiental relacionada à qualidade da água para consumo humano. Brasília, 2014.

BRASIL. Ministério da Saúde. Indicadores institucionais do Programa Nacional de Vigilância da Qualidade da Água para Consumo Humano 2018. Brasília, DF, 2018. Available at: http://bvsms.saude.gov.br/bvs/publicacoes/indicadores_programa_nacional_qualidade_a gua_2018.pdf. Access: 19 jul. 2019.

BRITO, C. S. et al. Vigilância da concentração de flúor nas águas de abastecimento público na cidade de Passo Fundo - RS. Cadernos Saúde Coletiva, v. 24, n.4, p. 452-459, 2016. http://dx.doi.org/10.1590/1414-462x201600040240

BUZALAF, M. A. R. et al. Seven years of external control of fluoride levels in the public water supply in Bauru, São Paulo, Brazil. Journal of Applied Oral Science, v. 21, n. 1, p. 92 98, 2013. http://dx.doi.org/10.1590/S0034-89102006005000005

CAMPOS, M. A. et al. Análise do gerenciamento do heterocontrole da fluoretação das águas de abastecimento público de um município de médio porte no estado do Espírito Santo. Revista Brasileira de Pesquisa em Saúde, v. 17, n. 3, p. 89-97, 2015. https://doi.org/10.21722/rbps.v17i3.14140

CARVALHO, R. A. S. et al. Desigualdades em saúde: condições de vida e mortalidade infantil em regiões do nordeste do Brasil. Revista de Saúde Pública, v. 49, p. 5, 2015. http://10.1590/S0034-8910.2015049004794

CECOL/USP. Documento de consenso técnico: classificação de águas de abastecimento público segundo o teor de flúor. In: SEMINÁRIO VIGILÂNCIA DA FLUORETAÇÃO DE ÁGUAS, 2011, São Paulo. Arquivos[...] São Paulo: Faculdade de Saúde Pública, Universidade de São Paulo, 2011.

CESA, K.; ABEGG, C.; AERTS, D. R. G. C. A vigilância da fluoretação de águas nas capitais brasileiras. Epidemiologia e Serviços de Saúde, v. 20, n. 4, p. 547-555, 2011. http://dx.doi.org/10.5123/S1679-49742011000400014

FISCHER, T. K. et al. Indicadores de atenção básica em saúde bucal: associação com as condições socioeconômicas, provisão de serviços, fluoretação de águas e a estratégia de saúde da família no Sul do Brasil. Revista Brasileira de Epidemiologia, v. 13, n. 1, p. 126-138, 2010. https://doi.org/10.1590/S1415-790X2010000100012

FERNANDES, L. S.; PERES, M. A. Associação entre a atenção básica em saúde bucal e indicadores socioeconômicos municipais. Revista de Saúde Pública, v. 39, n. 6, p. 930936, 2005. http://dx.doi.org/10.1590/S0034-89102005000600010

FRAZÃO, P.; NARVAI, P. C. Cobertura e vigilância da fluoretação da água no Brasil: municípios com mais de 50 mil habitantes. São Paulo: Faculdade de Saúde Pública da USP, 2017. https://doi.org/10.11606/9788588848252

FRAZÃO, P.; NARVAI, P. C. Fluoretação da água em cidades brasileiras na primeira década do século XXI. Revista de Saúde Pública, v. 51, n. 47, p. 1-11, 2017. http://dx.doi.org/10.1590/s1518-8787.2017051006372 
FRAZÃO, P. et al. Fluoretação da água e insuficiências no sistema de informação da política de vigilância à saúde. Revista da Associação Paulista de Cirurgiões Dentistas [online], v. 67, n. 2, p. 94-100, 2013.

IHEOZOR-EJIOFOR, Z. et al. Water fluoridation fluoridation for the prevention of dental caries. Cochrane Database of Systematic Reviews, v. 6, p. 1 - 274, 2015. http://10.1002/14651858.CD010856.pub2

IBGE. Pesquisa Nacional de Saneamento Básico. Rio de Janeiro, 2017. Available at: https://cidades.ibge.gov.br/brasil/es/pesquisa/30/84366. Access: 20 jul. 2019.

MOIMAZ, S. A. S. et al. Dificuldades enfrentadas no processo de fluoretação das águas de abastecimento público. Revista Brasileira de Pesquisa em Saúde, v. 17, n. 1, p. 87-94, 2015. https://doi.org/10.21722/rbps.v17i1.12455

OLIVEIRA JUNIOR, A. et al. Sistema de Informação de Vigilância da Qualidade da Água para Consumo Humano (Sisagua): características, evolução e aplicabilidade. Epidemiologia e Serviços de Saúde, v. 28, n.1, p. e2018117, 2019. https://dx.doi.org/10.5123/S167949742019000100024

PELLETIER A. R. Maintenance of optimal fluoride levels in public water systems. Journal of Public Health Dentistry, v. 64, n. 4, p. 237-239, 2004. https://doi.org/10.1111/j.17527325.2004.tb02759.x

PETERSEN, P. E. The World Oral Health Report 2003: continuous improvement of oral health in the 21st century-the approach of the WHO Global Oral Health Programme. Community Dent Oral Epidemiol, v. 31, n. 1, p. 3-24, 2003. https://dx.doi.org/10.1046/j..2003.com122.x

PIORUNNECK, C. M. O; DITTERICH, R. G.; GOMES, E. C. Heterocontrole da fluoretação nos municípios da Região Metropolitana de Curitiba nos anos de 2014 e 2015. Cadernos de Saúde Coletiva, v. 25, n. 4, p. 414-422, 2017. http://dx.doi.org/10.1590/1414$462 \times 201700040171$

PNUD. Atlas do Desenvolvimento humano no Brasil. Brasília, 2010. Available at: http://www.atlasbrasil.org.br/2013/ Access: 20 abr. 2018.

QUEIROZ, A. C. L. et al. Programa Nacional de Vigilância em Saúde Ambiental Relacionada à Qualidade da Água para Consumo Humano (Vigiagua): lacunas entre a formulação do programa e sua implantação na instância municipal. Saúde e Sociedade, v. 21, n. 2, p. 465-478, 2012. http://doi.org/10.1590/S0104-12902012000200019

RONCALLI, A.G. et al. Fluoretação da água no Brasil: distribuição regional e acurácia das informações sobre vigilância em municípios com mais de 50 mil habitantes. Cadernos de Saúde Pública, v. 35, n. 6, p. e00250118, 2019. http://dx.doi.org/10.1590/0102$311 \mathrm{x} 00250118$

SCALIZE, P. S. et al. Heterocontrole da fluoretação da água de abastecimento público em cidades do estado de Goiás, Brasil. Ciência \& Saúde Coletiva, v. 23, n. 11, p. 38493860, 2018. http://dx.doi.org/10.1590/1413-812320182311.24712016

SLADE, G. D. et al. Water fluoridation and dental caries in US children and adolescents. Journal of Dental Research, v. 97, n. 10, p. 1122-1128, 2018. https://doi.org/10.1177/0022034518774331 
SPENCER, A. J.; DO, L. G.; HA, D. H. Contemporary evidence on the effectiveness of water fluoridation in the prevention of childhood caries. Community Dent Oral Epidemiol, v. 46, n. 4, p. 407-415, 2018. https://doi.org/10.1111/cdoe.12384

TUCCI C. et al. Scenarios of water management in Brazil: a contribution to the "World Water Vision". Revista Brasileira de Recursos Hídricos, v. 5, n. 3, p. 31-43, 2000. http://doi.org/10.21168/rbrh.v5n3.p31-43

VENTURINI, C. Q. et al. Vigilância e monitoramento de fluoretos em águas de abastecimento público: uma revisão sistemática. Revista Ambiente \& Água, v. 11, n. 4, p. 972-988, 2016. http://dx.doi.org/10.4136/ambi-agua.1929.

WHO. Diarrhoea: why children are still dying and what can be done. 2009. Available at: https://www.who.int/maternal_child_adolescent/documents/9789241598415/en/. Access: 20 jul. 2019. 